\title{
Discovery and characterization of an immunogenic neoantigen in a patient with metastatic triple negative breast cancer
}

Yasmine Assadipour ${ }^{1}$, Stephanie Goff ${ }^{2}$, Jessica S Crystal ${ }^{3}$, Todd D Prickett ${ }^{4}$, Jared J Gartner ${ }^{5}$, Robert Somerville ${ }^{6}$, Hui X $u^{6}$, Mary Black ${ }^{6}$, Isaac Kriley ${ }^{6}$, Paul F Robbins ${ }^{5}$, Steven A Rosenberg ${ }^{5}$, Steven Feldman ${ }^{6}$

From 30th Annual Meeting and Associated Programs of the Society for Immunotherapy of Cancer (SITC 2015) National Harbor, MD, USA. 4-8 November 2015

A growing body of evidence suggests that successful clinical immunotherapy may depend on mutation-specific $\mathrm{T}$ cell responses. Using whole-exome and RNA sequencing of a resected metastatic deposit from a patient with triple-negative (ER-, PR-, Her2 non-amplified) breast cancer, we identified 72 non-synonymous mutations. Using previously published methods of autologous antigen presentation[1], we identified a novel non-synonymous mutation in a regulator of the Notch signaling pathway, RBPJ (recombination signal binding protein for immunoglobulin kappa J region), that encodes a neoantigen specifically recognized by autologous CD4+ tumor infiltrating lymphocytes. Antigen recognition was restricted by the Class II DR locus. Deep sequencing or PCR of all 16 metastases collected at autopsy revealed that the mutation was ubiquitously present in all samples. To the best of our knowledge, this represents the first report of an immunogenic mutation in breast cancer.
doi:10.1186/2051-1426-3-S2-P284

Cite this article as: Assadipour et al.: Discovery and characterization of an immunogenic neoantigen in a patient with metastatic triple negative breast cancer. Journal for ImmunoTherapy of Cancer 20153 (Suppl 2):P284.

\begin{abstract}
Authors' details
${ }^{1}$ George Washington University, Washington, DC, USA. ${ }^{2}$ Surgery Branch, NIH/ $\mathrm{NCl}$, Bethesda, MD, USA. ${ }^{3} \mathrm{NCl} / \mathrm{NIH}$, Rutgers Robert Wood Johnson Medical School, New Brunswick, NJ, USA. ${ }^{4} \mathrm{NCI} / \mathrm{NIH}$, Bethesda, MD, USA. ${ }^{5}$ Surgery Branch/National Cancer Institute/National Institutes of Health, Bethesda, MD, USA. ${ }^{6} \mathrm{NIH} / \mathrm{NCl}$, Bethesda, MD, USA.

Published: 4 November 2015

\section{Reference}

1. Tran E, Turcotte $S$, Gros A, et al: Cancer immunotherapy based on mutation-specific CD4+ T cells in a patient with epithelial cancer. Science 2014 344:641-5.
\end{abstract}

${ }^{2}$ Surgery Branch, $\mathrm{NIH/NCl}$, Bethesda, MD, USA

Full list of author information is available at the end of the article
Submit your next manuscript to BioMed Central and take full advantage of:

- Convenient online submission

- Thorough peer review

- No space constraints or color figure charges

- Immediate publication on acceptance

- Inclusion in PubMed, CAS, Scopus and Google Scholar

- Research which is freely available for redistribution 